DOI: $10.21802 /$ artm.2019.3.11.78.

УДК [616.62-006.04-036.87-018.74:576.385.5]-091.8

\title{
ЗНАЧЕНИЕ АНГИОГЕНЕЗА В ПРОГНОЗЕ РЕЦИДИВИРОВАНИЯ И ПРОГРЕССИИ НЕИНВАЗИВНОГО УРОТЕЛИАЛЬНОГО РАКА МОЧЕВОГО ПУЗЫРЯ
}

\author{
И.И. Яковцова, Е.В. Титов, И.В. Ивахно
}

Харьковская академия последипломного образования, кафедра патологической анатомии, 2. Харьков, Украина,

ORCID ID: 0000-0002-1027-9215,

ORCID ID: 0000-0002-1999-3052,

ORCID ID: 0000-0002-5229-0068,

e-mail: titovevgeniy@ukr.net

Резюме. Целью работы являлось изучение ангиогенеза в неинвазивных уротелиальных раках мочевого пузыря (НУРМП) для выявления критериев рецидивирования и прогрессии заболевания.

Материалы и методы. Материалом послужили оперативно удаленные в Харьковском областном клиническом центре урологии и нефрологии им. В. И. Шаповалова уротелиальные раки мочевого пузыря стадии $\mathrm{T} 1$, то есть без инвазии в мышечный слой стенки органа, числом 42 случая. Средний возраст пациентов составил 66,4 $\pm 7,2$ лет, мужчин было 83,3\% (35/42), женщин $-16,7 \%$ (7/42).

Материал был распределён на группы: НУРМП без рецидивирования - I группа (14 случаев), НУРМП с рецидивированием без прогрессии - II группа (14 случаев) и НУРМП с рецидивированием и прогрессией в виде инвазии в мышечный слой стенки - III группа (14 случаев).

Результаты и их обсуждение. ПМС в НУРМП составила $32,71 \pm 4,22$ и варьировала от 12,8 до 44,6. ПМС в строме НУРМП повышалась при возрастании степени злокачественности опухоли, но уровень васкуляризации не оказывал прямого влияния на прогноз заболевания. В НУРМП высокой степени злокачественности отмечалась более интенсивная экспрессия VEGF и большее значение ПМС, чем в НУРМП низкой степени злокачественности ( $<0,03$ и $\mathrm{p}<0,01$ соответственно). Различия между группами исследования по показателям ПМС и экспрессии VEGF не достоверны (p>0,05).

Выводы. Подтверждена роль VEGF в неонгиогенезе НУРМП, что определяется прямой корреляционной зависимостью между уровнем экспрессии VEGF и ПМС ( $\mathrm{r}=0,677, \mathrm{p}<0,05)$. По мере снижения дифференцировки НУРМП отмечается возрастание васкуляризации опухоли $(\mathrm{p}<0,01)$, что обусловлено возрастанием экспрессии VEGF опухолевыми клетками $(\mathrm{p}<0,03)$. Исследованные показатели неоангиогенеза ПМС и VEGF - имеют ограниченное значение для прогноза рецидивирования и прогрессии НУРМП.

Ключевые слова: неинвазивный уротелиальный рак мочевого пузыря, неоангиогенез, плотность микрососудов, VEGF.

Вступление. Уротелиальный рак является наиболее часто встречающейся гистологической формой рака мочевого пузыря (РМП), который в 75\% случаев выявляется на этапе мышечно-неинвазивного роста [1]. Несмотря на многообразие прогностических алгоритмов, используемых в современной практике для оценки риска развития рецидива и прогрессии неинвазивного уротелиального РМП (НУРМП), отмечено не совпадение результатов лечения с ожидаемым течением заболевания: рецидив возможен в $30-85 \%$ случаев, а прогрессирование заболевания возникает в $10-30 \%$ [2]. Представляет научный и практический интерес исследование и поиск более четких морфологических и иммуногистохимических критериев прогноза клинического поведения НУРМП для улучшения дифференциального подхода к лечению пациентов.

Обоснование исследования. Важным прогностическим критерием, который связан с увеличением риска возникновения метастазов у больных злокачественными заболеваниями, является ангиогенез в строме опухоли. Во многих солидных опухолях в качестве маркера повышенного ангиогенеза используется сосудистый эндотелиальный фактор роста (VEGF) [3]. Прогностическая ценность тканевой экспрессии VEGF в УРMП остается неясной: есть данные, что высокий уровень VEGF связан с худшей выживаемостью и более высокими показателями рецидивов и метастазирования [4], но в ряде научных работ приводятся противоречивые результаты [5]. Также по данным некоторых авторов при повышении стадии УРМП и степени его злокачественности, увеличивается плотность микрососудов (ПМС) опухоли, но этот критерий нельзя использовать, как самостоятельный прогностический показатель [6]. Перспективным является дальнейшее изучение иммуногистохимических маркеров неоангиогенеза НУРМП, которое поможет установить более четкие критерии агрессивного биологического поведения опухолей и быть использовано для антиангиогенной терапии.

Цель исследования. Изучить ангиогенез в НУРМП для выявления критериев рецидивирования и прогрессии заболевания. 
Материалы и методы. Материалом послужили оперативно удаленные в Харьковском областном клиническом центре урологии и нефрологии им. В.И. Шаповалова уротелиальные раки мочевого пузыря стадии Т1, то есть без инвазии в мышечный слой стенки органа, числом 42 случая. Средний возраст пациентов составил $66,4 \pm 7,2$ лет, мужчин было $83,3 \%$ (35/42), женщин -16,7\% (7/42).

Материал был распределён на группы: НУРМП без рецидивирования - I группа (14 случаев), НУРМП с рецидивированием без прогрессии - II группа (14 случаев) и НУРМП с рецидивированием и прогрессией в виде инвазии в мышечный слой стенки - III группа (14 случаев).

С целью исключения влияния на результаты исследования фактора дифференцировки опухоли, в каждой из групп исследования было взято равное число случаев НУРМП высокой и низкой степени злокачественности: по 8 НУРМП низкой степени злокачественности (НУР НС3) и по 6 случаев НУРМП высокой степени злокачественности (НУР ВС3). Дифференцировка раков учитывалась согласно последней классификации ВО3 2016 г. [7].

Иммуногистохимическое исследование проводилось с использованием первичных моноклональных антител (MКАТ) фирмы DAKO (Дания), Readyto-Use к CD 34 - маркеру эндотелиальных клеток для подсчета ПМС и VEGF - фактора неоангиогенеза. Для подсчета ПМС (по методу vascular hot spot) были отобраны пять областей с наибольшим числом сосудов и под большим увеличением (× 400) вычислена средняя их плотность. ПМС со значениями от 0 до 25 считалась низкой, от 26 до 50 - умеренной, свыше 51 - высокой. Уровень экспрессии VEGF оценивался по общепринятой полуколичественной шкале: 0 - отсутствие экспрессии, 1 - 1-10\% экспрессирующих мар- кер клеток в поле зрения, 2 - 11- 50\% клеток, 3 более $50 \%$ клеток.

Для статистического исследования связи между признаками применялись непараметрические методы Спирмана и хи-квадрат Пирсона. Для установления различия между группами исследования использовался t-критерий Стьюдента. Статистически значимым считалось значение $\mathrm{p}<0,05$.

Результаты и их обсуждение. ПМС в НУРМП составила $32,71 \pm 4,22$ и варьировала от 12,8 до 44,6. ПМС вблизи эпителиального пласта опухоли была значительно больше, чем в прочих участках стромы. Некоторые сосуды имели ветвистое строение. Встречалось много незрелых сосудов, имеющих маленький диаметр с узким или практически не различимым просветом.

Обнаружены статистически значимые различия в показателях ПМС в зависимости от степени дифференцировки НУРМП. Так, низкий уровень васкуляризации (ПМС менее 25) наблюдался в 58,3\% (14/24) НУР НСЗ и лишь в 11,1\% (2/18) НУР ВС3 $\left.\mathrm{x}^{2}=5,56 \mathrm{p}<0,01\right)$. Соответственно умеренный уровень васкуляризации со значением показателя ПМС от 26 до 50 среди НУР НС3 был в 41,7\% (10/24), среди НУР ВС3 - в 88,9\% (16/18) (p<0,01). Таким образом, ПМС в строме НУРМП повышалась при возрастании степени злокачественности опухоли, но уровень васкуляризации не оказывал прямого влияния на прогноз заболевания (см. таблицу 1): различия между группами исследования по показателю ПМС не достоверны ( $>0,05)$. В нерецидивирующих НУРМП (І группы) среднее значение ПМС составило $27,94 \pm 2,9$ и было несколько ниже, чем в группе рецидивирующих ра-

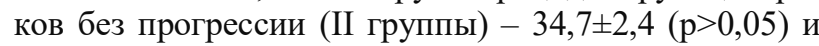
чем в группе рецидивирующих раков с прогрессией $35,4 \pm 2,6(\mathrm{p}>0,05)$.

Таблица 1

Плотность микрососудов в строме НУРМП и группы исследования

\begin{tabular}{|c|c|c|c|c|}
\hline \multirow{2}{*}{ Показатель } & \multicolumn{3}{|c|}{ Группы исследования } & Достоверность, \\
\cline { 2 - 4 } & $\mathrm{I}$ & $\mathrm{II}$ & $\mathrm{III}$ \\
& $\mathrm{n}(\%)$ & $\mathrm{n}(\%)$ & $4(28,6 \%)$ & \\
\hline ПМСерий $\mathrm{x}^{2}$ & $\mathrm{x}^{2}=1,07 \mathrm{p}=0,58$ \\
умеренная & $8(57,1 \%)$ & $4(28,6 \%)$ & $10(71,4 \%)$ & $\mathrm{x}^{2}$ crit $\left.=5,99\right)$ \\
\hline VEGF 1+ & $6(42,9 \%)$ & $10(71,4 \%)$ & $3(21,4 \%)$ & $\mathrm{x}^{2}=0,7 \mathrm{p}=0,70$ \\
$2+$ & $4(28,6 \%)$ & $5(35,7 \%)$ & $11(78,6 \%)$ & $\left(\mathrm{x}^{2} \_\right.$crit $\left.=5,99\right)$ \\
\hline
\end{tabular}

Неоангиогенез в УРМП является динамическим процессом, регулируемым факторами роста, среди которых VEGF, фибробластический фактор роста (bFGF), цитокины (IL8), ферменты (матриксные металлопротеиназы), белки экстрацеллюлярного матрикса и прочие медиаторы. VEGF играет основную роль в неоангиогенезе путем регулирования пролиферации эндотелиоцитов, их миграции и ремоделирования капилляров с образованием сосудистых просветов [8]. В нашем исследовании выявлена положительная корреляционная связь средней силы между уровнем экспрессии VEGF и ПМС ( $\mathrm{r}=0,677, \mathrm{p}<0,05)$. Так, слабая экспрессия VEGF наблюдалась в 28,6\% (12/42) случаев, при этом среднее значение ПМС составило $21,7 \pm 6,0$, умеренная экспрессия VEGF наблюдалась в

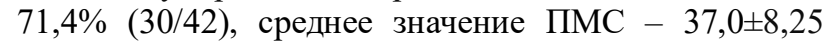
$(\mathrm{p}<0,001)$.$) . Таким образом, доказана роль VEGF в$ процессах васкуляризации НУРМП.

В НУР ВСЗ отмечалась более интенсивная экспрессия VEGF, чем в НУР НC3. Так, низкий уровень реакции VEGF (до $10 \%$ опухолевых клеток) наблюдался в 41,7\% (10/24) НУР НС3 и лишь в 11,1\% (2/18) НУР ВС3 $\left.\mathrm{x}^{2}=4,7 \mathrm{p}<0,03\right)$. Соответственно умеренный уровень экспрессии VEGF (с реакцией 11$50 \%$ опухолевых клеток) среди НУР НС3 был в 58,3\% (14/24), среди НУР ВСЗ - в 88,9\% (16/18) (p<0,03).

Обнаруженная зависимость между 
дифференцировкой НУРМП и показателями неоангиогенеза - экспрессией опухолевыми клетками VEGF и ПМС в строме, а также корреляционная зависимость между этими показателями, - указывают на роль опухолевых клеток в неоангиогенезе по средствам экспрессии ими VEGF и возрастании неоангиогенеза по мере снижения дифференцировки опухоли.

При рассмотрении экспрессии VEGF в НУРМП в зависимости от их принадлежности к группам исследования, выявлен примерно одинаковый уровень реакции: средняя экспрессия VEGF в I группе составила $1,71 \pm 0,46$, во II группе $1,64 \pm 0,49$, в III группе $-1,78 \pm 0,42$, что указывает на ограниченное значение VEGF для прогноза рецидивирования и прогрессии заболевания.

\section{Выводы:}

1. Подтверждена роль VEGF в неоангиогенезе НУРМП, что определяется прямой корреляционной зависимостью между уровнем экспрессии VEGF и $\Pi \mathrm{MC}(\mathrm{r}=0,677, \mathrm{p}<0,05)$.

2. По мере снижения дифференцировки НУРМП отмечается возрастание васкуляризации опухоли $(\mathrm{p}<0,01)$, что обусловлено возрастанием экспрессии VEGF опухолевыми клетками $(\mathrm{p}<0,03)$.

3. Исследованные показатели неоангиогенеза - ПМС и VEGF - имеют ограниченное значение для прогноза рецидивирования и прогрессии НУРМП.

\section{References:}

1. Zheng L, Zhu Y, Lei L, Sun W, Cheng G, Yang S. Significant expression of CHK1 and p53 in bladder urothelial carcinoma as potential therapeutic targets and prognosis. Oncol Lett. 2018, Jan; 15(1):568-574. Published online 2017; Nov, 3. doi: 10.3892/ol.2017.7344 PMCID: PMC5769388 PMID: 29391889

2. Choi W, Czerniak B, Ochoa A et al. Intrinsic basal and Iuminal subtypes of muscle-invasive bladder cancer. Nat. Rev. Urol. 2014; 11:400-410. doi: 10.1038/nrurol.2014.129. Epub 2014; Jun, 24.

3. Fus LP, Górnicka P. Role of angiogenesis in urothelial bladder carcinoma.

Cent European J Urol. 2016; 69(3):258-263. doi: 10.5173/ceju.2016.830 PMCID: PMC5057050 PMID: 27729991

4. Zhang B, Wu Z, Xie W, Tian D, Chen F, Qin C, Du Z, Tang G, Gao Q, Qiu X, Wu C, Tian J, Hu H. The expression of vasohibin-1 and its prognostic significance in bladder cancer. Exp Ther Med. 2017, Oct; 14(4):34773484. Published online 2017; Aug, 18. doi: 10.3892/etm.2017.4969. PMCID: PMC 5639 433. PMID: 29042936.

5. Kopparapu PK, Boorjian SA, Robinson BD, Downes M, Gudas LJ, Mongan NP, Persson JL. Expression of VEGF and its receptors VEGFR1/VEGFR2 is associated with invasiveness of bladder cancer. Anticancer Res. 2013; 33:2381-2390. PMID:23749886

6. GuoY, Zhu T, Zhuang G, Zhang S, Qi L, Li W, Zang Y. Astrocyte elevated gene-1 expression in urothelial bladder carcinoma and its clinical significance. Int J Clin Exp Pathol. 2016; 9(12):12779-12784. www.ijcep.com /ISSN:1936-2625/IJCEP0040279.
7. Moch H, Humphrey PA, Ulbright TM, Reuter V. The 2016 WHO Classification of Tumours of the Urinary System and Male Genital Organs. Lyon, France; International Agency for Research of Cancer; European Urology. 2016; 70:101-119. doi: 10.1016/j.eururo.2016.02.028. Epub 2016; Mar, 17.

8. Adelmann T, Ioiart I, Ceausu R, Sarb S, Suciu C. Immunohistochemical expression of vascular endothelial growth factor does not correlate with microvessel density in invasive bladder carcinoma. Research and Clinical Medicine. 2018; 2(1):12-17.

\section{УДК [616.62-006.04-036.87-018.74:576.385.5]-091.8 ЗНАЧЕННЯ АНГІОГЕНЕЗУ В ПРОГНОЗІ РЕЦИДИВУ І ПРОГРЕСІЇ НЕІНВАЗИВНОГО УРОТЕЛІАЛЬНОГО РАКУ СЕЧОВОГО МІУУРА}

\section{I. І. Яковцова, Є. В. Титов, І. В. Івахно}

Харківська академія післядипломної освіти, кафедра патологічної анатомії, м. Харків, Украӥна,

ORCID ID: 0000-0002-1027-9215,

ORCID ID: 0000-0002-1999-3052,

ORCID ID: 0000-0002-5229-0068,

e-mail: titovevgeniy@ukr.net

Резюме. Метою роботи було вивчення ангіогенезу в неінвазивних уротеліальних раках сечового міхура (НУРСМ) для виявлення критеріїв рецидивування і прогресії захворювання.

Матеріали та методи. Матеріалом послужили оперативно видалені в Харківському обласному клінічному центрі урології та нефрології ім. В. І. Шаповалова уротеліальні раки сечового міхура стадії $\mathrm{T} 1$, таким чином без інвазії в м'язовий шар стінки органа, числом 42 випадки. Середній вік пацієнтів склав $66,4 \pm 7,2$ років, чоловіків було $83,3 \%$ (35/42), жінок $16,7 \%(7 / 42)$.

Матеріал був розподілений на групи: НУРСМ без рецидивування - I група (14 випадків), НУРСМ 3 рецидивуванням без прогресії - II група (14 випадків) і НУРСМ з рецидивуванням і прогресією у вигляді інвазії в м'язовий шар стінки - III група (14 випадків).

Результати та їх обговорення. ЩМС в НУРСМ склала $32,71 \pm 4,22$ і варіювала від 12,8 до 44,6. ЩМС в стромі НУРСМ підвищувалася при зростанні ступеня злоякісності пухлини, але рівень васкуляризації не чинив прямого впливу на прогноз захворювання. У НУРСМ високого ступеня злоякісності відзначалися більш інтенсивна експресія VEGF і більше значення ЩМС, ніж в НУРСМ низького ступеня злоякісності ( $p<0,03$ і $\mathrm{p}<0,01$ відповідно). Відмінності між групами дослідження за показниками ЩМС і експресії VEGF не достовірні (p>0,05).

Висновки. Підтверджено роль VEGF в неоангіогенезі НУРСМ, що визначається прямою кореляційною залежністю між рівнем експресії VEGF i ЩМС ( $\mathrm{r}=0,677, \mathrm{p}<0,05)$. У міру зниження диференціювання НУРСМ відзначається зростання васкуляризації пухлини ( $<0,01)$, що обумовлено зростанням експресії VEGF пухлинними клітинами ( $<<0,03)$. 
Досліджені показники неоангіогенезу - ЩМС і VEGF - мають мало для прогнозу рецидивування і прогресії НУРСМ.

Ключові слова: неінвазивний уротеліальний рак сечового міхура, неоангіогенез, щільність мікросудин, VEGF.

\section{UDC [616.62-006.04-036.87-018.74:576.385.5]-091.8 \\ THE IMPORTANCE OF ANGIOGENESIS IN THE FORECAST OF RECURRENCE AND PROGRESSION OF A NON-INVASIVE UROTELIAL BLADDER CANCER}

\section{I.I. Yakovtsova, E.V. Titov, I.V. Ivakhno}

Kharkiv Academy of Postgraduate Education, Department of Pathological Anatomy, Kharkiv, Ukraine, ORCID ID: 0000-0002-1027-9215,

ORCID ID: 0000-0002-1999-3052, ORCID ID: 0000-0002-5229-0068, e-mail: titovevgeniy@ukr.net

Abstract. The aim of the work was to study angiogenesis in non-invasive urothelial cancers of the bladder (NUCB) to identify the criteria for recurrence and progression of the disease.

Materials and methods. The material, urothelial cancers of the bladder stage T1, without invasion into the muscular layer of the wall of the organ, was obtained in the Kharkiv Regional Clinical Center of Urology and Nephrology named after V.I. Shapovalov. The number is 42 cases. The average age of patients was $66.4 \pm 7.2$ years; men were $83.3 \%$ (35/42), women $-16.7 \%(7 / 42)$. The material was divided into groups: NUCB without recurrence - group I (14 cases), NUCB with recurrence without progression - group II (14 cases) and NUCB with recurrence and progression in the form of invasion into the muscular layer of the wall - group III (14 cases).

In order to exclude the effect on the study results of tumor differentiation factor, in each of the study groups an equal number of cases of high and low grade NUCB were taken: eight low grade NUR NUCB and six cases of high grade NUCB. Cancer differentiation was taken into account according to the latest WHO classification, 2016.

Results and discussion. Microvessel density (MVD) in NUCB was $32,71 \pm 4,22$ and ranged from 12.8 to 44.6. MVD in the stroma of NUCB increased with an increase in the degree of tumor malignancy, but the level of vascularization did not directly affect the prognosis of the disease - differences between groups of studies in terms of MVD are not significant $(p>0.05)$. A positive correlation was found between the level expression of VEGF and MVD $(r=0.677, \mathrm{p}<0.05)$. So weak expression of VEGF was observed in $28.6 \%(12 / 42)$ cases, while the average MVD was $21.7 \pm 6.0$; moderate expression of VEGF was observed in $71.4 \%(30 / 42)$, the average MVD value was $37.0 \pm 8.25(\mathrm{p}<0.001)$. The VEGF expression in high grade NUCB was more intense than in low grade NUCB. So a low level of VEGF reaction (up to $10 \%$ of tumor cells) was observed in $41.7 \%(10 / 24)$ of the low grade NUCB and only in $11.1 \%(2 / 18)$ of the high grade NUCB $(\chi 2=4.7 \mathrm{p}<0,03)$. Accordingly, a moderate level of VEGF expression (with a reaction in $11-50 \%$ of tumor cells) among low grade NUCB was 58.3\% (14/24), among high grade NUCB it was $88.9 \%(16 / 18)(\mathrm{p}<0,03)$.

The found relationship between NUCB differentiation and neoangiogenesis indicators expression of VEGF in tumor cells and MVD of the stroma, as well as correlation between these marks indicate the role of tumor cells in neoangiogenesis through VEGF expression of them and increasing neoangiogenesis as tumor differentiation decreases.

Considering the expression of VEGF in NUCB, depending on their belongings to the study groups, approximately the same reaction level was detected: the average expression of VEGF in group I was $1.71 \pm 0.46$, in group II $-1.64 \pm 0.49$, in III group - $1.78 \pm 0.42$, which indicates a limited value of VEGF for the prediction of recurrence and progression of the disease.

Conclusions. The role of VEGF in neoangiogenesis of NUCB was confirmed, which is determined by the direct correlation between the expression level of VEGF and DMV $(r=0.677, p<0.05)$. As the NUCB differentiation decreases, an increase in tumor vascularization is observed $(p<0.01)$, which is caused by an increase in VEGF expression by tumor cells $(p<0.03)$. The studied indices of neoangiogenesis - DMV and VEGF - are of limited importance for the prediction of recurrence and progression of NUCB.

Keywords: noninvasive urothelial cancer of the bladder, neoangiogenesis, density of microvessels, VEGF. 